\title{
Intensitas Bermain Game Online Mobile PlayerUnknown's Battleground (PUBG) dengan Kecenderungan Agresivitas pada Dewasa Awal
}

\author{
Reza Teofanda \\ Fakultas Psikologi, Universitas Muhammadiyah Malang \\ E-mail: rezateo27@gmail.com
}

\begin{abstract}
Mobile online gaming is now the trend is mobile battleground playerunknown's game (PUBGM). In that type of game Battle Royale game, players are required to compete to survive and kill other players. This gives rise to controversy one of which is related as a result of aggressiveness. This research aims to know the relationship between the intensity of playing online games with aggressiveness. The study uses a quantitative research approach with correlational research design. The subject in this study amounted to 201 participants taken using the Purposive sampling technique by assigning special characteristics that fit the research objectives. The instruments used are the Likert scale Brief Aggression Questionnaire (BAQ) and the intensity scale. The result from this study was analyzed using SPSS 25 with product moment Pearson correlation technique where the coefficient of determination (R2) amounted to 0.16 and the correlation coefficient $(r) 0.40$ amounting to significance value of $0.000<0.05$. It can be said there is a positive and significant relationship with moderate levels between intensity and aggressiveness. Thus the more a person has a high intensity then the greater the tendency of aggressiveness on them.
\end{abstract}

KEYWORDS Intensity, aggressiveness, Online games, early adult.

CITATION Teofanda, R. (2020). Intensitas bermain game online mobile playeruknown's battleground (pubg) dengan kecenderungan agresivitas pada dewasa awal. Cognicia, 8, (1), 461-473.

Salah satu game online mobile yang sekarang menjadi tren adalah game PlayerUnknown's Battleground Mobile (PUBGM). Game online mobile ini banyak dimainkan mulai dari rentang usia remaja sampai dewasa awal. Dari keseluruhan survei yang sudah dilakukan, pemain terbanyak di dalam game online mobile ini adalah mereka yang berusia dewasa awal.

Player Unknown's Battlegrounds (PUBG) Mobile dirilis untuk platform Android dan iOS pada Maret 2018. Popularitas game besutan Tencent tersebut dengan cepat menanjak hingga sekarang tercatat sudah diunduh sebanyak 100 juta kali di toko aplikasi Android Google Play Store. Di Play Store, PUBG Mobile menjadi game terlaris nomor 4 setelah Mobile Legends, Garena Free Fire, dan Lords Mobile. Pendapatannya juga termasuk paling tinggi. Pada September lalu PUBG Mobile tercatat memiliki pengguna aktif harian (daily active user) sebanyak 20 juta. Ada game battle royale lain bernama Fortnite, namun pembuatnya, Epic Games, tidak menyalurkan game ini lewat Google Play Store sehingga menghambat popularitasnya di platform Android (Kompas.com). 
Tencent mengklaim bahwa jumlah pemain terbanyak kedua berasal dari Indonesia. Meski begitu, ia tidak membeberkan berapa jumlah pengguna aktif bulanan PUBG Mobile di Indonesia secara rinci. Ia hanya mengatakan Indonesia merupakan pasar yang penting dan besar bagi PUBG Mobile (Idnnews.id). Berdasarkan hal tersebut dapat dilihat bahwa game PUBGM saat menjadi tren dan banyak dimainkan.

Dalam PUBGM yang berjenis game Battle Royale pemain diharuskan berkompetisi untuk bertahan hidup dan membunuh pemain lain dengan senjata, granat atau kendaraan dalam sebuah peta yang sudah disediakan sampai pemain tersebut menjadi pemain terakhir yang bertahan hidup. Dan untuk pemenang permainan akan mendapatkan sebuah gelar pemenang makan malam ayam (winner-winner chicken dinner). Dari jenis dan alur permainan yang mengandung kekerasan dan pembunuhan. Berdasarkan hal tersebut diduga PUBM rentan menimbulkan agresivitas.

Dari survei yang dilakukan oleh Kompas.com diperoleh hasil dengan basis gamers di Indonesia terdiri dari 49\% pengguna ponsel laki-laki dan 51\% pengguna ponsel perempuan, dari rentang usia 16-24 tahun dari basis keseluruhan para gamers (Kompas.com). Hasil survei tersebut dapat diketahui bahwa pemain game online terbanyak di Indonesia adalah mereka yang tergolong ke dalam usia remaja dan dewasa awal.

Sedangkan dari hasil survey awal pada 19 Juni 2019 terhadap 92 partisipan yang tergabung sebagai anggota komunitas gamer Malang Raya. Game yang sering mereka mainkan adalah game playeruknown's battleground mobile (PUBGM), mereka memainkan game tersebut untuk mengisi waktu kosong, menghilangkan kejenuhan serta terdapat beberapa dari mereka memainkan game tersebut dengan tujuan menjadi gamer, yaitu menjadikan bermain game sebagai profesi dengan cara sering mengikuti perlombaan. Mereka yang tergabung dalam komunitas tersebut memiliki rentang usia antara 21-25 tahun. Dari hasil tersebut terlihat rentang usia mereka termasuk ke dalam golongan usia dewasa awal.

Dewasa awal merupakan masa peralihan dari masa remaja. Menurut Santrock (2002), masa dewasa awal adalah masa untuk berkerja dan menjalin hubungan dengan lawan jenis, terkadang menyisakan sedikit waktu untuk hal lainnya. Transisi dari masa remaja ke dewasa disebut sebagai masa beranjak dewasa yang terjadi dari usia 18 sampai 25 tahun. Masa ini ditandai oleh eksperimen dan eksplorasi, dimana banyak individu melakukan eksplorasi jalur karir yang ingin mereka tekuni, ingin menjadi individu yang seperti apa, dan gaya hidup seperti apa yang mereka inginkan, hidup melajang, hidup bersama, atau menikah (Arnett dalam Santrock, 2002).

Di indonesia PUBGM menjadi sorotan dan kontroversi setelah terjadi penembakan brutal oleh teroris di dua masjid di Selandia Baru. MUI masih melakukan kajian mendalam sebagai dasar pertimbangan dalam mengeluarkan fatwa. Majelis Ulama Indonesia (MUI) sedang mengkaji fatwa haram atau tidaknya game PUBGM (detik.com). Hal ini dikarenakan game PUBGM dianggap membawa dampak buruk yang mengarah kepada agresivitas terutama kekerasan, sehingga game PUBGM dinilai membawa dampak sikap radikal terorisme dalam diri seseorang yang memainkan game tersebut.

Sedangkan peristiwa yang terjadi di Belagavi, Karnataka, India, Minggu (8/9/2019) malam, dimana pria berusia 25 tahun, Raghuveer Kumbar, tega membunuh 
ayahnya. Karena kesal diminta berhenti bermain PUBG. Mereka bertengkar setelah beradu argumen soal kecanduan PUBG hingga menyebabkan mahasiswa politeknik tersebut lupa waktu. Pertengkaran pun berujung pada pembunuhan terhadap Shankar yang merupakan pensiunan polisi. Sementara itu, kepolisian Karnataka mengungkap, usai membunuh, Raghuveer memutilasi ayahnya dengan memenggal kepala dan memotong tangannya (inews.id). Berdasarkan kasus ini terlihat bahwa ketika seseorang bemain game PUBG dengan durasi waktu yang lama berdampak pada munculnya agresivitas terutama kekerasan terhadap orang lain.

Agresi adalah kebutuhan untuk menyerang, memperkosa atau melukai orang lain, untuk meremehkan, merugikan, mengganggu, membahayakan, merusak, menjahati, mengejek, mencemooh atau menuduh secara jahat, menghukum berat, atau melakukan tindakan sadistik lainnnya (Muray dalam Chaplin, 2005). Perilaku agresi adalah cara untuk melawan dengan sangat kuat melalui berkelahi, melukai, menyerang, membunuh, atau menghukum orang lain. Singkatnya agresi adalah tindakan yang dimaksudkan untuk melukai orang lain atau merusak milik orang lain. Hal yang terjadi pada saat tawuran sebenarnya merupakan perilaku agresi dari seorang individu atau kelompok.

Berdasarkan dari hasil wawancara awal pada 17 Juli 2019 yang dilakukan terhadap 7 partisipan yang tergabung sebagai anggota komunitas gamer Malang Raya, didapatkan hasil bahwa tujuan awal partisipan bermain game online yaitu untuk menghilangkan kejenuhan tidak tercapai. Ketika bermain game PUBGM gejala emosional dan agresivitas terlebih dalam bentuk verbal dirasakan oleh partisipan. Hal tersebut terjadi ketika patisipan sudah bermain dengan durasi waktu yang lama.

Hasil dari penelitian Tobing (2015) didapatkan korelasi yang kuat antara durasi bermain game online terhadap gejala emosional, korelasi sedang antara durasi bermain game online terhadap masalah perilaku, hiperaktivitas, masalah hubungan antar sesama, dan tidak terdapat hubungan antara durasi bermain game online terhadap perilaku prososial. Berdasarkan penelitian tersebut terlihat adanya hubungan intensitas dalam bermain game online dengan gejala emosional. Dimana dengan adanya intensitas dalam bermain game online, hal tersebut dapat menjadikan salah satu faktor pencetus munculnya perilaku agresif.

Sedangkan dari hasil penelitian Abdul Basith (2017) menunjukkan adanya hubungan yang positif dengan tingginya intensitas bermain game online yang ditunjukkan pada anggota komunitas gaming Surabaya, berjalan searah dengan tingginya tingkat kecenderungan agresivitas pada anggota komunitas gaming Surabaya. Hal ini disebabkan semakin tinggi frekuensi dan lama waktu seseorang ketika bermain game online maka peluang untuk munculnya kekalahan dan hambatan pada saat bermain game online semakin tinggi. Berdasarkan penelitian tersebut dapat dilihat bahwa intensitas bermain game online menjadi faktor yang dapat memunculkan kecenderungan agresivitas.

Dalam pendekatan situasional, kondisi situasional merupakan pencetus (trigger) munculnya perilaku agresi. Beberapa tokoh penting yang tergabung dalam pendekatan ini, Bushman dan Cooper, Carlson, Marcus-Newhall dan Miller, Chermack dan Giancola serta Anderson dan Anderson (dalam Susantyo, 2011), menyebutkan 
bahwa pendekatan ini meyakini bahwa perilaku agresi bukan faktor bawaan (naluri) yang ada pada setiap individu.

Dimana dunia sosial di dalam game online dapat mempengaruhi seseorang untuk berperilaku agresi baik secara fisik, verbal, emosinal dan permusuhan. Hal ini bisa terjadi ketika seseorang yang bermain game online bersama-sama kemudian mengalami kekalahan atau tidak kompak dalam bekerja sama ketika bermain, sehingga dapat memunculkan perilaku agresi pada salah satu individu. Perilaku agresi tersebut dapat mempengaruhi dan menular pada individu lain, ini disebabkan adanya proses belajar sosial ketika mereka bermain. Sedangkan menurut Bandura (dalam Susantyo, 2011) menyatakan bahwa perilaku agresi merupakan hasil dari proses belajar sosial (Social Learning) melalui pengamatan terhadap dunia sosial.

Salah satu faktor penyebab agresi pada game online adalah intensitas bermain game online yang tinggi. Intensitas artinya kedalaman atau kekuatan terhadap sesuatu yang diukur dari waktu yang dipergunakan. Sedangkan agresivitas merupakan perilaku yang dilakukan untuk menyakiti, mengancam, atau membahayakan individuindividu atau objek-objek yang menjadi sasaran perilaku tersebut.

Oleh karena itu, penelitian ini bertujuan untuk mengetahui hubungan antara tingkat kecenderungan agresivitas dengan intensitas bermain game online pada dewasa awal. Sehingga manfaat teoritis penelitian ini adalah untuk mengetahui bagaimana tingkat agresivitas seorang gamer ketika memiliki intensitas bermain yang tinggi. Serta manfaat praktis penelitian ini nantinya dapat bermanfaat untuk penelitian selanjutnya sebagai salah satu sumber wawasan guna meminimalisir terjadinya agresivitas agar tercipta generasi muda yang taat beragama dan terhindar dari perbuatan saling menyakiti antar sesama.

\section{METODE}

Penelitian ini menggunakan pendekatan penelitian kuantitatif. Penelitian kuantitatif adalah suatu penelitian yang menggunakan pendekatan deduktif-induktif dengan data penelitian yang berupa angka-angka dan analisis menggunakan statistik. Desain penelitian yang digunakan adalah penelitian dengan teknik korelasi product moment pearson. Penelitian korelasi adalah suatu penelitian untuk mengetahui hubungan dan tingkat hubungan antara dua variabel atau lebih tanpa ada upaya untuk mempengaruhi variabel tersebut sehingga tidak terdapat manipulasi variabel (Notoatmodjo, 2010).

Subyek dalam penelitian ini adalah individu dewasa awal. Penelitian ini menggunakan teknik purposive sampling. Teknik purposive sampling adalah salah satu teknik sampling non random sampling dimana peneliti menentukan pengambilan sampel dengan cara menetapkan ciri-ciri khusus yang sesuai dengan tujuan penelitian sehingga diharapkan dapat menjawab permasalahan penelitian. Ciri-ciri khusus dalam pengambilan sampel sebagai berikut: Bermain game PUBGM, berusia 18 sampai 25 tahun (Dewasa awal) dan pemain game PUBGM 1 jam per hari.

Pada penelitian ini terdapat dua variabel yaitu variabel bebas $(X)$ dan variabel terikat $(\mathrm{Y})$. Adapun yang menjadi variabel bebas $(\mathrm{X})$ yaitu, intesitas bermain game dan yang menjadi variabel terikat $(\mathrm{Y})$ adalah agresivitas. Intensitas bermain game adalah waktu yang dihabiskan individu dalam bermain game online. Agresivitas adalah suatu 
bentuk perilaku atau aksi agresi yang diungkapkan untuk menyakiti orang lain, perilaku agresi dapat berbentuk fisik, verbal, kemarahan dan permusuhan.

Skala Intensitas dibuat berdasarkan aspek intensitas yang didapat dari definisi menurut Chaplin (2004), Random House Unabridged Dictionary (1997), Nashori (2006), yaitu: frekuensi, lama waktu, perhatian penuh dan emosional. Metode skala yang digunakan, disajikan dalam bentuk pernyataan-pernyataan. Seluruh pernyataan dalam skala ini bersifat favorable, berbentuk skala jenjang yang mengungkap intensitas kejadian dengan menggunakan empat pilihan jawaban yang berbentuk a, b, c, d. Skala ini merupakan adopsi dari skala intensitas yang telah ditryout oleh peneliti sebelumnya dengan indeks validitas 0,331-0,785 dan koefisien reliabilitas sebesar 0,906.

Sedangkan untuk skala agresivitas dibuat berdasarkan beberapa aspek yang dibagi menjadi empat jenis, yaitu physical, verbal, anger, dan hostility (Buss \& Perry, 1992). Instrumen yang digunakan untuk mengukur perilaku agresi berjenis skala Likert. Dimana seluruh pernyataan dalam skala ini adalah favorable. Skala ini menggunakan empat pilihan jawaban, yaitu sangat setuju, setuju, tidak setuju, dan sangat tidak setuju. Skala ini merupakan adopsi bentuk ringkas dari skala agresivitas yang dikembangkan oleh Buss dan Perry (1992), yang dinamakan Brief Aggression Questionnaire (BAQ) yang telah ditryout oleh peneliti sebelumnya, dengan indeks validitas 0,54-0,96 dan koefisien reliabilitas sebesar 0,81.

Tabel 1. Indeks Validitas dan Reliabilitas Alat Ukur Penelitian

\begin{tabular}{ccccc}
\hline Alat Ukur & $\begin{array}{c}\text { Jumlah Item } \\
\text { Diujikan }\end{array}$ & $\begin{array}{c}\text { Jumlah Item } \\
\text { Valid }\end{array}$ & Indeks Validitas & $\begin{array}{c}\text { Indeks } \\
\text { Reliabilitas }\end{array}$ \\
\hline Agresivitas & 25 & 17 & $0,362-0,790$ & 0,937 \\
Intensitas & 20 & 15 & $0,295-0,789$ & 0,925 \\
\hline
\end{tabular}

Berdasarkan hasil tryout yang telah dilakukan pada 50 subyek menunjukkan bahwa, pada skala agresi dari 25 aitem yang diujikan terdapat 17 aitem valid dan 8 aitem tidak valid. Indeks validitas skala agresi berkisar antara 0,362-0,790. Sementara pada skala intensitas dari 20 aitem yang diujikan, diperoleh 15 aitem valid dan 5 aitem tidak valid dengan indeks validitas skala intensitas berkisar antara 0,295-0,789.

Dari kedua instrumen yang diujikan dapat dikatakan reliabel karena reliabilitas dari kedua instrumen $>0,60$ (Croanbach Alpha). Nilai reliabilitas pada skala agresi sebesar 0,937, sedangkan nilai reliabilitas pada skala intensitas sebesar 0,925. Dapat disimpulkan bahwa instrumen yang digunakan dalam penelitian ini valid dan reliabel.

Dalam penelitian terdapat beberapa prosedur yang akan dilakukan. Pertama adalah persiapan, peneliti menggali fenomena yang sedang terjadi, dimana fenomena ini akan diteliti dan dijadikan sebagai variabel penelitian. Setelah menemukan variabel penelitian, peneliti melakukan kajian pustaka dari sumber-sumber seperti jurnal, buku-buku, ataupun penelitian-penelitian sebelumnya.

Selanjutnya peneliti menentukan rancangan penelitian yang akan dilakukan dengan menggunakan metode yang tepat untuk penelitian tersebut. Peneliti kemudian mempersiapkan skala yang akan digunakan untuk mengukur variabel penelitian. 
Langkah selanjutnya, peneliti melakukan tryout atau uji coba pada skala tersebut. Kemudian, peneliti melakukan uji validitas dan reliabilitas dengan menggunakan program perhitungan statistik SPSS 25 untuk mendapatkan item yang valid.

Prosedur kedua adalah tahap pelaksanaan, setelah didapatkan item yang valid peneliti memberika skala penelitian kepada subyek yang sesuai dengan kriteria penelitian. Peneliti memberikan instrument penelitian melalui media sosial dengan bantuan google form. Pemilihan subyek pada penelitian ini menggunakan teknik purposive sampling yaitu teknik pengambilan subyek dengan pertimbangan tertentu yang dianggap paling tahu atau sesuai dengan kriteria yang dibutuhkan peneliti.

Prosedur terakhir yaitu analisis terhadap hasil yang diperoleh dari pegambilan data menggunakan bantuan program perhitungan Statistical Package for Social Science (SPSS) 25, merupakan analisis statistik parametrik. Peneliti akan menggunakan teknik korelasi product moment pearson yang termasuk dalam alat uji statistika. Setelah dilakukan analisis menggunakan SPSS peneliti membuat laporan hasil penelitian.

\section{HASIL}

Berdasarkan penelitian yang telah dilakukan, diperoleh hasil perhitungan kategorisasi dari seluruh responden. Adapun hasil perhitungan yang telah dilakukan adalah sebagai berikut :

Tabel 2. Deskripsi Subyek

\begin{tabular}{lcc}
\hline & Frekuensi & Presentase \\
\hline Usia & & \\
$18-20$ tahun & 134 & $66,7 \%$ \\
21-23 tahun & 67 & $33,3 \%$ \\
\hline Jenis Kelamin & & \\
Laki-laki & 188 & $93,5 \%$ \\
Perempuan & 13 & $6,5 \%$ \\
\hline Total & $\mathbf{2 0 1}$ & $\mathbf{1 0 0} \%$ \\
\hline
\end{tabular}

Tabel di atas menunjukkan hasil dari deskripsi subyek dalam penelitian ini adalah dewasa awal berusia 18-25, dengan rentang usia 18-20 tahun sebanyak 134 $(66,7 \%)$ subyek, dan untuk rentang usia $21-23$ tahun sebanyak $67(33,3 \%)$ subyek. Total subyek dalam penelitian ini adalah 201 orang, dengan jumlah 188 (93,5\%) laki-laki dan $13(6,5 \%)$ perempuan. Sedangkan, untuk keseluruhan lama bermain game online subyek yaitu lebih dari 1 jam sehari semua.

Tabel 3. Data Intensitas Bermain Subyek dalam Seminggu

\begin{tabular}{|c|c|c|}
\hline $\begin{array}{c}\text { Jumlah Bermain dalam } \\
\text { Seminggu }\end{array}$ & Frekuensi & Presentase \\
\hline$<5$ kali & 65 & $32,3 \%$ \\
\hline 7-14 kali & 108 & $53,7 \%$ \\
\hline > 14 kali & 28 & $13,9 \%$ \\
\hline Total & 201 & $100 \%$ \\
\hline
\end{tabular}


Berdasarkan tabel di atas menunjukkan bahwa dalam penelitian ini jumlah subyek yang bermain kurang dari 5 kali dalam seminggu sebanyak 65 (32,3\%) subyek. Kemudian untuk subyek yang bermain antara 7-14 kali dalam seminggu sebanyak 108 $(53,7 \%)$ subyek. Sedangkan untuk subyek yang bermain lebih dari 14 kali dalam seminggu sebanyak $28(13,9 \%)$ subyek.

Tabel 4. Data Intensitas Bermain Subyek dalam Sehari

\begin{tabular}{|c|c|c|}
\hline $\begin{array}{c}\text { Jumlah Bermain dalam } \\
\text { Sehari } \\
\end{array}$ & Frekuensi & Presentase \\
\hline 1-2 jam & 69 & $34,3 \%$ \\
\hline 3-6 jam & 105 & $52,2 \%$ \\
\hline$>6$ jam & 27 & $13,4 \%$ \\
\hline Total & 201 & $100 \%$ \\
\hline
\end{tabular}

Berdasarkan tabel di atas menunjukkan subyek yang bermain antara 1-2 jam sehari sebanyak 69 (34,3\%) subyek. Kemudian subyek yang bermain antara 3-6 jam sebanyak $105(52,2)$ subyek. Sedangkan subjek yang bermain lebih dari 6 jam dalam sehari sebanyak $27(13,4 \%)$ subyek.

Tabel 5. Uji Normalitas Intensitas dan Agresivitas

\begin{tabular}{lccccc}
\hline & \multirow{2}{*}{$\mathbf{N}$} & \multicolumn{2}{c}{ Skewness } & \multicolumn{2}{c}{ Kurtosis } \\
\cline { 3 - 6 } & & Statistic & Std. Error & Statistic & Std. Error \\
\hline Intensitas & & 287 &, 172 &,- 470 &, 341 \\
Agresivitas & 201 &, 031 &, 172 &,- 561 &, 341 \\
Valid N (listwise) & & & & & \\
\hline
\end{tabular}

Dari tabel di atas dapat dilihat skewness dan kurtosis intensitas antara 0,287 dengan -0,470. Sedangkan nilai skewness dan kurtosis agresivitas antara 0,031 dengan 0,561 . Sehingga data dinyatakan normal karena hasil dari berada di antara +2 dan -2 kedua variabel tersebut berada di antara +2 dan -2 . Maka data tersebut dapat dikatakan berdistribusi normal.

Tabel 6. Uji Linearitas Data Intensitas dan Agresivitas

\begin{tabular}{lccc}
\hline & & $\mathrm{F}$ & Sig. \\
\hline Intensitas & Between Groups(Combined) & 2,824 &, 000 \\
Agresi & Linearity &, 379 &, 000 \\
& $\begin{array}{l}\text { Deviation from } \\
\text { Linearity }\end{array}$ & 1,482 &, 068 \\
\hline
\end{tabular}

Dari tabel, dapat dilihat nilai signifikansi dari kedua variabel tersebut diperoleh nilai signifikan deviation from linearity 0,068 dimana lebih besar dari 0,05 (0,068 > $\mathrm{p}=0,05)$, yang artinya bahwa data antara variabel tersebut linear. 
Tabel 7. Hasil Perhitungan Kategori Intensitas dan Agresivitas

\begin{tabular}{|c|c|c|c|c|c|c|}
\hline Variabel & $\mathbf{M}$ & SD & Kategori & Interval & F & Presentase \\
\hline \multirow{2}{*}{ Agresivitas } & \multirow{2}{*}{39,81} & \multirow{2}{*}{6,249} & Tinggi & $43-68$ & 66 & $32,8 \%$ \\
\hline & & & Rendah & $17-42$ & 135 & $67,2 \%$ \\
\hline \multirow{2}{*}{ Intensitas } & \multirow{2}{*}{32,09} & \multirow{2}{*}{6,631} & Tinggi & $38-60$ & 42 & $20,9 \%$ \\
\hline & & & Rendah & $15-37$ & 159 & $79,1 \%$ \\
\hline
\end{tabular}

Tabel di atas menunjukkan kategori variabel agresi dengan skor rata-rata sebesar 39,81 dan standard deviasi sebesar 6,249. Pada variabel agresivitas responden pada kategori tinggi sejumlah 66 (32,8\%) subyek. Sedangkan dengan kategori rendah sejumlah $135(67,2 \%)$ subyek. Sementara pada variabel intensitas diperoleh rata-rata sebesar 32,09 dengan standar deviasi 6,631. Responden pada kategori tinggi sejumlah $42(20,9 \%)$ subyek. Sedangkan dengan kategori rendah sejumlah $159(79,1 \%)$ subyek.

Tabel 8. Korelasi Intensitas dan Agresivitas

\begin{tabular}{lc}
\hline & Indeks Analisis \\
\hline Koefisien Korelasi $(\mathbf{r})$ & 0,40 \\
Koefisien Determinasi $\left(\mathbf{r}^{2}\right)$ & 0,16 \\
Nilai signifikansi $(\mathbf{p})$ & 0,000 \\
\hline
\end{tabular}

Berdasarkan hasil analisa data yang telah dilakukan dengan menggunakan teknik analisa korelasi product moment pearson, diperoleh koefisien korelasi ( $\mathrm{r}$ ) sebesar 0,40 dengan nilai signifikansi (p) sebesar 0,000 < 0,05. Dapat dikatakan bahwa terdapat hubungan yang positif dan signifikan antara kedua variabel. Semakin tinggi variabel intensitas maka akan semakin tinggi variabel agresi. Semakin rendah variabel intensitas maka akan semakin rendah variabel agresi. Pada hasil analisa diperoleh koefisien determinasi $\left(\mathrm{r}^{2}\right)$ sebesar 0,16, dapat dikatakan bahwa kontribusi intensitas terhadap agresivitas adalah sebesar $16 \%$ dan sisanya $84 \%$ dipengaruhi oleh variabel yang lain yang tidak dimasukkan dalam penelitian ini. Sedangkan koefisien korelasi (r) sebesar 0,40 juga berarti terdapat tingkat hubungan sedang antara kedua variabel.

\section{DISKUSI}

Penelitian ini dilakukan untuk mengetahui hubungan intensitas bermain game online PUBGM terhadap kecenderungan agresivitas pada dewasa awal. Dari hasil analisa data yang telah dilakukan dengan menggunakan teknik korelasi product moment pearson diperoleh koefisien determinasi $\left(\mathrm{r}^{2}\right)$ sebesar 0,16 dan koefisien korelasi (r) 0,40 sebesar dengan nilai signifikansi sebesar 0,000<0,05. Hal ini dapat dikatakan terdapat hubungan yang positif dan signifikan dengan tingkat sedang antara kedua variabel. Semakin tinggi seseorang bermain game online maka akan semakin tinggi kecenderungan agresivitanya, begitu pula sebaliknya. Dengan demikian hipotesis dalam penelitian ini diterima.

Penelitian ini sejalan dengan penelitian yang dilakukan oleh La Febrina (2014) bahwa individu yang memilki intensitas tinggi dalam bermain game online lebih menunjukkan perilaku agresi. Hal ini dikarenakan individu terlalu sering 
menyaksikan aktivitas yang mengandung perilaku agresi di dalam permainan tersebut. Sedangkan pada kelompok individu yang memilki intensitas rendah cenderung tidak melakukan perilaku agresi. Hal ini dikarenakan individu hanya menjadikan kegiatan bermain game online sebagai sarana hiburan saja.

Hasil deskripsi subyek penelitian menunjukkan bahwa jumlah subyek sebanyak 201 orang, 188 (93,5\%) laki-laki dan 13 (6,5\%) perempuan. Dapat diketahui bahwa subyek dalam penelitian ini didominasi oleh laki-laki. Adapun dari keseluruhan subyek, memiliki intensitas bermain game online lebih dari 1 jam sehari. Sedangkan, untuk rentang usia subyek, diperoleh hasil usia 18-20 tahun sebanyak 134 (66,7\%) subyek, dan usia 21-23 tahun sebanyak 67 (33,3\%) subyek.

Data tersebut menunjukkan bahwa usia terbanyak terdapat pada rentang usia 18-20 tahun sebanyak 134 (66,7\%) subyek. Usia ini merupakan masa peralihan subyek dari masa remaja menuju dewasa, dimana mereka masih memanfaatkan kebebasan yang diperoleh. Salah satu contohnya adalah sebagian besar subyek memanfaatkan waktunya untuk bermain game. Sedangkan hasil terendah ada pada rentang usia 21-23 tahun sebanyak $67(33,3 \%)$ subyek. Dimana individu pada rentang usia ini sudah melakukan penyesuaian diri dengan kehidupan. Mereka sudah memikirkan gaya hidup seperti apa yang mereka inginkan, sehingga banyak individu yang sudah mengekplorasi jalur karir mereka. Selain itu, mereka juga sudah memilih untuk hidup melajang, hidup bersama atau menikah. Hurlock (1986) mengemukakan salah satu inti dari karakteristik dewasa awal adalah masa penyesuaian diri dengan cara hidup baru dan memanfaatkan kebebasan yang diperoleh.

Berdasarkan hasil pengkategorian diperoleh hasil untuk variabel agresivitas dengan skor rata-rata sebesar 39,81 pada responden yang memiliki kategori tinggi sejumlah 66 (32,8\%) subyek. Sedangkan kategori rendah sejumlah 135 (67,2\%) subyek. Sementara pada variabel intensitas diperoleh skor rata-rata sebesar 32,09 dengan responden pada kategori tinggi sejumlah 42 (20,9\%) subyek. Sedangkan pada kategori rendah sejumlah $159(79,1 \%)$ subyek. Sehingga dapat disimpulkan dalam peneltian ini diperoleh hasil dari keseluruhan subyek penelitian memiliki intensitas bermain dengan kecenderungan agresivitas yang rendah.

Berdasarkan penelitian sebelumnya Setiawati \& Gunado (2019) menemukan bahwa individu yang bermain Mobile Legends dan PUBG Mobile menunjukkan perilaku agresif paling tinggi dibandingkn individu yang bermain game online lain. Mobile Legends dan PUBG Mobile merupakan salah satu game online yang di dalamnya mengandung unsur-unsur kekerasan, seperti memukul karakter lawan, menembak menggunakan senjata, mencabik-cabik menggunakan pedang, dan masih banyak lagi yang dapat membuat individu meniru konten di dalam game terkait. Selain itu, faktor tren game Mobile Legends dan PUBG Mobile membuat pemainnya berbondong-bondong ingin mencoba memainkan, dan pada akhirnya membuat pemain menjadi ketagihan.

Penelitian ini sejalan dengan penelitian tersebut dimana seseorang yang bermain game PUBG Mobile cenderung agresif dikarenakan adanya faktor penularan perilaku yang disebabkan seringnya seseorang melihat tayangan perilaku agresi. Menurut Bandura (dalam Susantyo, 2011) beranggapan bahwa perilaku agresif merupakan sesuatu yang dipelajari, buka perilaku yang dibawa individu sejak lahir Perilaku 
agresif ini dipelajari dari lingkungan sosial seperti interaksi dengan keluarga, interaksi dengan rekan sebaya dan media massa melalui modelling.

Selain itu, dalam penelitian Setiawati \& Gunado (2019) mengemukakan bahwa faktor sosial sangat berpengaruh, dimana peneliti melakukan wawancara terhadap salah satu subyek penelitian yang memainkan game Mobile Legends dan PUBG Mobile menyatakan bahwa dalam kehidupan sehari-hari subyek tersebut lebih memilih berdiam diri dirumah dan bermain game online sampai larut malam dari pada bermain dengan temannya di luar rumah, artinya kehidupan sosial subyek tersebut rendah. Sedangkan menurut penelitian Majorsy, Kinasih, Andriani, dan Lisa (2013) seseorang yang mempunyai keterampilan sosial rendah, cenderung lebih banyak menggunakan media sosial maupun media game, bahkan hingga ke taraf yang dikatakan kecanduan (addiction).

Intensitas bermain game online yang tinggi juga dapat menimbulkan adanya penularan perilaku agresi dari hasil sosialisasi antar pemain dalam game online. Hal ini terjadi karena game online menjadi sarana pelarian yang aman untuk memenuhi kebutuhan sosial atau kebutuhan hiburan. Bartle (dalam Bainbridge, 2010: 48-49) mengatakan salah satu motivasi gamer dalam bermain game online yaitu, bersosialisasi dengan gamer lain (socializers).

Kontribusi intensitas terhadap agresivitas dalam penelitian ini sebesar $16 \%$ sedangkan $84 \%$ dipengaruhi oleh variabel yang lain. Menurut La Febrina (2014) terdapat berbagai faktor yang dapat membuat seseorang berperilaku agresif. Faktorfaktor yang dapat menyebabkan seseorang berperilaku agresif adalah kondisi lingkungan, pengaruh kelompok, kondisi fisik, biologis, frustrasi, kesalahpahaman, instruksi langsung, penguatan, modeling, kurangnya pengetahuan dan keterampilan, keluarga, dan media. Berdasarkan faktor-faktor tersebut game online merupakan salah penyebab seseorang dapat berperilaku agresif yang termasuk dalam faktor modeling dan media.

Penelitian ini menghasilkan skor rata-rata variabel Intesitas sebesar (X) 32,09 dengan nilai presentase $79,1 \%$ yang termasuk dalam kategori rendah. Sehingga tingkat intensitas partisipan yang ditandai dengan frekuensi, lama waktu, perhantian penuh dan emosional ketika bermain game online berada pada kategori rendah. Sedangkan skor rata-rata variabel perilaku agresivitas (Y) sebesar 39,81 dengan nilai presentase $67,2 \%$ yang termasuk dalam kategori rendah. Sehingga dapat disimpulkan bahwa tingkat agresi partisipan yang ditandai dengan agresi fisik, agresi verbal, kemarahan dan permusuhan masih dalam kategori rendah.

Hasil penelitian ini menunjukkan bahwa terdapat hubungan positif antara intensitas dengan agresivitas. Semakin tinggi intensitas seseorang bermain game online maka semakin tinggi kecenderungan perilaku agresif yang dimiliki, begitu pula sebaliknya. Hasil ini sejalan dengan hasil penelitian sebelumnya Haqq (2016), dimana dalam penelitian tersebut menunjukkan bahwa terdapat hubungan positif dan signifikan antara intensitas bermain game online dengan agresivitas pada usia remaja. Dengan demikian individu pada masa dewasa awal dengan intensitas bermain online game yang tinggi, semakin besar kecenderungan memiliki perilaku agresif yang tinggi dan begitu sebaliknya. 
Kelebihan dalam penelitian ini yaitu tema baru yang diteliti relevan dengan permasalahan yang terjadi saat ini. Sedangkan analisis dalam penelitian dilakukan hanya sebatas untuk mengetahui hubungan intesitas dengan agresivitas tanpa mendalami masing-masing aspeknya. Selain itu penelitian juga bersifat online dan self report dimana keduanya dapat menimbulkan bias, selain itu, penelitian ini bersifat korelasi dan bukan sebab akibat.

\section{SIMPULAN DAN IMPLIKASI}

Hasil penelitian ini sesuai dengan hipotesa yang diajukan, artinya terdapat hubungan yang positif dan signifikan antara intensitas dengan agresivitas. Sehingga dapat disimpulkan bahwa semakin tinggi intensitas yang dimiliki seseorang dalam bermain online game semakin besar kecenderungan agresivitas pada dirinya, begitu sebaliknya.

Implikasi dari penelitian ini dapat menjadi acuan agar tidak menaruh perhatian penuh pada game online dengan mengurangi intensitas waktu bermain game online, disarankan bagi para pemain game PUBGM untuk tidak bermain lebih dari 5 kali dalam seminggu dengan kisaran waktu 1-2 jam dalam sehari .

Penelitian ini juga diharapakan menjadi informasi bagi mahasiswa maupun masyarakat umum mengenai agresivitas, sehingga dapat digunakan sebagai tindakan pencegahan untuk mengurangi berbagai permasalahan perilaku agresi yang muncul akibat dari intesintas bermain game online yang berlebihan. Penelitian ini memberikan rujukan atau bahan kajian bagi peneliti selanjutnya dan diharapkan bagi peneliti selanjutnya agar dapat mendalami setiap aspek dan melibatkan subyek yang beragam untuk menambah referensi mengenai penelitian ini.

\section{REFERENSI}

Abdul Basith A, M. 2017. Hubungan antara intensitas bermain game online dengan kecenderungan agresivitas pada komunitas gaming Surabaya. Character : Jurnal Penelitian Psikologi., 4(3).

Adams, E. \& Rollings, A. 2007. Fundamentals of Game Design. Prentice Hall.

Alwi, S. 2008. Manajemen Sumber Daya Manusia. Edisi Kedua. BPPE Yogyakarta.

Bainbridge, Stephen M. 2001. Limited Liability Companies : A Primer on Value Creation through Choice of Form. Corporation and Economics. Foundation Press.

Bandura, A. 1973. Aggression a Social Learning Analysis. New Jersey: PrenticeHall, Inc.

Berkowitz, L. 2003. Agresi 1. Jakarta: Pustaka Binaman Pressindo.

Buss, A.H \& Perry, M. 1992. The Aggression Questionnaire. Journal of Personality and Social Psychology. The American Psychological Association, Inc.

Chaplin, J. P. 1981. Kamus Lengkap Psikologi (Kartini Kartono Trans.). Jakarta: PT. RajaGrafindo Persada.

Chaplin, J.P. 2004. Kamus Lengkap Psikologi. Jakarta: PT Raja Grafindo Persada.

Chaplin, J.P. 2005. Kamus Lengkap Psikologi. Jakarta : Rajawali Pres

Davidoff, L. 1991. Psikologi Suatu Pengantar: Jilid 2. Alih Bahasa. Drs. Marijuniati. Jakarta: Erlangga

Dayakisni, T., \& Hudaniah. 2015. Psikologi sosial. Malang: UMM Press.

Dill, K.E. \& Dill. J.C, 1998. Video Game Violence: A Review of the Empirical Literature. Aggression and Violent Behavior, 3 (4), 407-428. 
Gentile, Douglas A and David A. Walsh. 2004. The effects of violent video game habits on adolescent hostility. aggressive behaviors and school performance. Journal of Adolescence 27 (2004) 5-22.

Grinder, R.E. 1978. Adoleseceant Second Edition. New York: John Wiley dan Sons,Inc.

Haqq, T. A. (2016). Hubungan antara intensitas bermain game online terhadap agresivitas remaja awal di warnet "A, B dan C" Kecamatan Lowokwaru Kota Malang. Doctoral dissertation, Universitas Islam Negeri Maulana Malik Ibrahim.

Hurlock, Elizabeth B, 1986, Developmental Psychology. $3^{\wedge}$ rd Ed, New Delhi: McGraw Hill, Inc.

Hurlock, E. B. 1994. Psikologi Perkembangan: Suatu Pendekatan Sepanjang Rentang Kehidupan. Jakarta: Erlangga.

La Febrina, C. 2014. Pengaruh Intensitas Bermain Game On-line Terhadap Agresivitas Siswa. Jurnal Ilmiah Visi, 9(1), 28-35.

Lewis, Marc D. \& Granic, Isabela. 2000. Emotion, Development, and Self- Organization. Dynamic Systems Approaches to Emotional Development. Cambridge: Cambridge University Press.

Lumban Gaol, Theresia. 2012. Hubungan Kecanduan Game online dengan Prestasi Akademik Mahasiswa di Fakultas Teknik Universitas Indonesia. Manuskip. skripsi Ilmu Keperawatan UI.

Majorsy, U., Kinasih, A. D., Andriani, I., \& Lisa, W. 2013. Hubungan antara Keterampilan Sosial dan Kecanduan Situs Jejaring Sosial pada masa Dewasa Awal. Prosiding PESAT, 5.

Morgan, C.T., King, R.A., Weisz, R.J. \& Schopler 1986. Introduction to Psychology. Seventh Edition. Mc.Graw Hill Co.

Murray, G., Rawlings, D., Allen, N.B. and Trinder, J. 2003. NEO Five-Factor Inventory scores: psychometric properties in a community sample. Measurement and Evaluation in Counselling and Development,36, 140-9

Nashori, F. 2006. Kepercayaan Diri dan Prestasi Atlet Tae Kwon Do Daerah Yogyakarta. Jurnal Psikologi. Semarang: Fakultas Psikologi UNDIP. Volume 3 No.1.

Notoatmodjo, S. 2010. Metodologi Penelitian Kesehatan. Jakarta: Rineka Cipta.

Poerwadarminta. W.J.S. 2003. Kamus Umum Bahasa Indonesia. Jakarta: Balai Pustaka

Random House Unabridged dictionary. copyright 1997. by Random House, Inc., on Infoplease. Intensiometer.

Santrock, John W. 1999. Life-span Development (7^^th edition). USA: McGraw Hill.

Santrock, J.W. 2002. Life-Span Development: Perkembangan Masa Hidup. Edisi kelima. Jilid 1. PT. Gelora Aksara Pratama. Jakarta: Erlangga.

Setiawati, O. R., \& Gunado, A. 2019. Gambaran Perilaku Agresif Pada Siswa Smp Yang Bermain Game Online. Jurnal Psikologi Malahayati, 1(1).

Subrahmanyam, K. et al. 2008. Online and offline social networks: Use of social networking sites by emerging adults. Journal of Applied Developmental Psychology. 29, 420-433.

Suryanto, R.N. 2015. Dampak Positif Dan Negatif Permainan Game online Dikalangan Pelajar. Jom FISIP. 2(2) : 11-12.

Susantyo, B. 2011. Memahami perilaku agresif: Sebuah tinjauan konseptual. Sosio Informa, 16(3).

Taylor, S. E., Peplau, L. A., \& Sears, D. O. 2009. Psikologi sosial (12 ed.). (T. B. Wibowo, Penerj.) Jakarta: kencana.

Tobing, I. D. L. 2015. Hubungan Durasi dan Frekuensi Bermain Game Online Dengan Masalah Mental Emosional pada Remaja di SMP Negeri 1 Medan. TA 2015/2016.

Sarlito. 1997. Individu Dan Teori-Teori Psikologi Sosial. Psikologi Sosial, Balai Pustaka. Jakarta.

Yanto, Riki. 2011. Pengaruh game online terhadap perilaku remaja. Skripsi (tidak diterbitkan). Universitas Andalas: Padang. 
https://www.idnnews.id/indonesia-jadi-negara-pemain-terbanyak-kedua-di-dunia-di-gamepubg-mobile/

https://www.inews.id/news/internasional/keji-pria-di-india-bunuh-dan-mutilasi-ayahnya-garagara-dilarang-main-pubg.

https://tekno.kompas.com/read/2018/10/16/19080037/game-pubg-mobile-diunduh-100-juta-kalidi-android.

https://news.detik.com/berita/d-4482124/mui-fatwa-haram-pubg-diputus-bulandepan?_ga=2.183924902.185278717.1557754257-676581812.1556641276. 